\title{
Continuous thrombocytopenia after SARS- CoV-2 nucleic acid negative in a non-severe COVID-19 patient for several months
}

\author{
Xia Wu', Dongxia Luo², Yaling Liu², Yilan Zeng ${ }^{2^{*+}}$ and Yuping Gong ${ }^{1 *+}$ (D)
}

\begin{abstract}
Background: Thrombocytopenia was common in the coronavirus disease (Covid-19) patients during the infection, especially in severe COVID-19 patients, but was less in the non-severe Covid-19 patients. However, the platelet count would be restored after antivirus treatment. In this paper, we report continuous thrombocytopenia in a nonsevere Covid-19 case after a negative nucleic acid test for Covid-19.
\end{abstract}

Case presentation: A non-severe COVID-19 patient had the platelet continuous decrease for several months after the SARS-CoV-2 nucleic acid turning negative, and without well response to the glucocorticoid. The dynamic change of platelet count followed that of the lymphocyte count. After excluding the medicines possibility, immune system disorders, other specific virus infection and specific antibody of platelet, the thrombocytopenia continuously lasted for several months. The upward trend did not begin until June 2020 and she took the tapering dose of prednisone under the instruction of the hematologist.

Conclusion: Excluding other potentialities inducing thrombocytopenia, we highly hypothesized the SARS-CoV-2 may cause thrombocytopenia by disturbing the immune system to induce the thrombocytopenia in our report, which needs longer time to restore the immune system and platelet count via the glucocorticoid. We firstly reported this case in order to contribute the clinician to better deal with the patients like this.

Keywords: Non-severe COVID-19, Continuous thrombocytopenia, SARS-CoV-2

\section{Background}

In December 2019, a cluster of unknown acute respiratory illness occurred in Wuhan, the capital city of Hubei province in China. Now the disease known as coronavirus disease (COVID-19) caused by severe acute respiratory syndrome coronavirus 2 (SARS-CoV-2) has since been declared a pandemic by the Word Health Organization on March 11, 2020 [1]. Fever, dry cough, fatigue, anorexia and dyspnea are common symptoms in patients with

\footnotetext{
* Correspondence: 2499081791@qq.com; gongyuping2010@aliyun.com tYilan Zeng and Yuping Gong contributed equally to this work. ${ }^{2}$ Department of Internal Medicine, The Public and Health Clinic Centre of Chengdu, Chengdu, China

'Department of Hematology, West China Hospital, Sichuan University, Chengdu, Sichuan Province, China
}

COVID-19, and the human-to-human transmission of COVID-19 has been confirmed [2]. Like SARS-CoV and MERS-CoV, SARS-CoV-2 has also been reported to induce thrombocytopenia, especially in severe COVID-19 [3-8], but the platelet count is restored after timely antivirus treatment. However, there is no report about significant reduction of platelets in non-severe COVID-19 patients following SARS-CoV-2 nucleic acid turning negative. Here, we report our first non-severe Covid-19 case of continuous thrombocytopenia after a negative nucleic acid test for Covid-19. We hypothesized that the continuous thrombocytopenia in this case was due to immune dysregulation, especially the $\mathrm{T}$ cells, such as $\mathrm{CD} 4+\mathrm{T}$ cells and CD8+ T cells, which was important for the immune system. As reported in the previous studies, $\mathrm{T}$ cells play a

(c) The Author(s). 2020 Open Access This article is licensed under a Creative Commons Attribution 4.0 International License, which permits use, sharing, adaptation, distribution and reproduction in any medium or format, as long as you give appropriate credit to the original author(s) and the source, provide a link to the Creative Commons licence, and indicate if changes were made. The images or other third party material in this article are included in the article's Creative Commons licence, unless indicated otherwise in a credit line to the material. If material is not included in the article's Creative Commons licence and your intended use is not permitted by statutory regulation or exceeds the permitted use, you will need to obtain permission directly from the copyright holder. To view a copy of this licence, visit http://creativecommons.org/licenses/by/4.0/. The Creative Commons Public Domain Dedication waiver (http://creativecommons.org/publicdomain/zero/1.0/) applies to the data made available in this article, unless otherwise stated in a credit line to the data. 
vital role in immune system and may affect the effective of glucocorticoid on the thrombocytopenia [9]. We defined the degree of severity of Covid-19 at the time admission according to the seventh Trial Version of the Novel Coronavirus Pneumonia Diagnosis and Treatment Guidance. The definition of continuous thrombocytopenia was the platelet count below 150 or $100 \diamond 10^{9} / \mathrm{L}$ for three to twelve months.

\section{Case presentation}

A 49-year-old woman had a history of fever on 2nd February 2020 after coming in contact with her husband who had been diagnosed with Covid-19. At that time, two throat and nasal swabs of SARS-CoV-2 nucleic acid were negative and the chest CT was normal, and the platelet count was $103 \diamond 10^{9} / \mathrm{L}$. On 9th February 2020, the woman was nucleic acid positive for Covid-19 after a bronchoalveolar lavage, and diagnosed with non-severe Covid-19 according to the seventh Trial Version of the Novel Coronavirus Pneumonia Diagnosis and Treatment Guidance. She was admitted to the designated hospital (the Public and Health Clinic Centre of Chengdu) to receive treatment. In the designated hospital, all reexamination indicators were normal except the absolute lymphocyte count and C-reactive protein (CRP) (Table 1). The initial treatment mainly included lopinavir/ritonavir tablets $(500 \mathrm{mg}$ bid). After an eight-day therapy in hospital, the nucleic acid test for SARS-CoV-2 turned negative for two consecutive tests, and other laboratory tests were normal as well (Table 1). Therefore, she was discharged from hospital on 18th February 2020.

Fourteen days after discharge, the patient presented with petechiae on the limbs, without mucous membrane bleeding (epistaxis or gum bleeding). But she did not go to see a doctor. Until on 4th March 2020, she accepted the regular review of laboratory tests and chest CT in the designated hospital, indicating that the platelet count was $45 \diamond 10^{9} / \mathrm{L}$ but other blood parameters were all normal (Table 1). The autoimmune antibody test was negative, including the anti-nuclear antibody (ANA), anti-Sm antibody, anti-U1-nRNP antibody, anti-SSA antibody, anti-SSB antibody, and other myositis antibodies. The hepatitis $B$ and $C$ virus markers were negative. Therefore, the patient was instructed by the doctor in the designated hospital to start to take Leucogen $(20 \mathrm{mg}$ tid) in the outpatient clinic for 2 weeks to increase platelet. This medicine, a cysteine derivative, could enhance the function of the bone marrow hematopoietic system to increase the platelet count. However, the purpura occurred on the lower limbs again after 7 days, she did not go to see a doctor until on 19th March 2020 for the second follow-up review. The platelet count was $15 \diamond 10^{9} / \mathrm{L}$, the purpura was also limited to the lower limbs at the same time, the CD4+ T cells reduced to 588 from 780 and CD8+ T cells from 412 to 346, but the other laboratory results were normal (Table 1). Given the severe thrombocytopenia, the patient was readmitted immediately in the designated hospital and hematologist prescribed $10 \mathrm{mg}$ dexamethasone intravenously and platelet transfusion to improve platelet to at least $30 \diamond 10^{9} / \mathrm{L}$. After the above treatment, the platelet count raised to $56 \diamond 10^{9} / \mathrm{L}$ next day, then prednisone $25 \mathrm{mg}$ twice a day with a gradually reduced dose to maintain the number of platelet about at $50 \diamond 10^{9} / \mathrm{L}$. Due to the recovery of platelet count, she was arranged to discharge on 20th March 2020.

On 27th March 2020, she went to see a hematologist with platelet count being $47 \diamond 10^{9} /$ Land started to increase the dose of prednisone to $30 \mathrm{mg} / \mathrm{d}$ till 10th April 2020 under the instruction of the hematologist. The platelet count increased to $69 \diamond 10^{9} / \mathrm{L}$ on 3rd April 2020, therefore, the dose of prednisone was tapered down from $30 \mathrm{mg}$ to $27.5 \mathrm{mg}$ on 10th April 2020. But on 16th April 2020, she complained of fatigue and general malaise and the platelet count was found to be $32 \diamond 10^{9} / \mathrm{L}$, therefore, the dose of prednisone increased to $50 \mathrm{mg}$ per day.. On April 21th, April 26th and May 1st, the platelet count was $62 \diamond 10^{9} / \mathrm{L}, 42 \diamond 10^{9} / \mathrm{L}$ and $40 \diamond 10^{9} / \mathrm{L}$, respectively. Under the instruction of the hematologist, she started to reduce $5 \mathrm{mg}$ of prednisone every week until 28 May 2020, and then reduce the $2.5 \mathrm{mg}$ dose every week. Due to the continuous reduction and instability of platelet count, hematologist advised her to complete a palate specific antibody test. She accepted the special antibody of platelet with all negative results, including GPIb/IX, GPIV, HPA-1a, 3a, 4a and HPA-1b,3b, 4a, HPA-5b,5a. The latest test of platelet was $121 \mathrm{~g} / \mathrm{L}$ on forth June 2020, and now she takes $17.5 \mathrm{mg}$ prednisone per day under the instruction of the hematologist (Fig. 1).

This patient, an employee in an education company, had no history of allergies, hepatitis and surgery. And she had no immune diseases, hyperthyroidism, chronic gastritis, diabetes, hypertension, heart disease, chronic lung disease, etc. The human immunodeficiency virus (HIV), hepatitis B and C virus, syphilis and venereal disease research laboratory tests were all negative (Table 2).

\section{Discussion and conclusion}

Many factors can induce secondary thrombocytopenia, such as immune disease, disseminated intravascular coagulation (DIC), thrombotic thrombocytopenic purpura (TTP), and antibiotics [10]. Among them, Virus-infection is a common cause. Like SARS-CoV and MERS-CoV viruses [3], SARS-CoV-2 may induce thrombocytopenia and the mechanism includes abnormal immune function, directly impairing bone marrow hemopoiesis $[11,12]$ and lung damage [13]. Previous studies have reported thrombocytopenia in patients with COVID-19 during the 
Table 1 The follow-up observation indicators of the patient

\begin{tabular}{|c|c|c|c|c|c|c|}
\hline Parameters & $\begin{array}{l}\text { First admission } \\
10 \mathrm{Feb}\end{array}$ & $\begin{array}{l}\text { Discharge } \\
18 \text { Feb }\end{array}$ & $\begin{array}{l}\text { First review } \\
4 \text { Mar }\end{array}$ & $\begin{array}{l}\text { Second review } \\
19 \text { Mar }\end{array}$ & $\begin{array}{l}\text { Third review } \\
20 \mathrm{Apr}\end{array}$ & $\begin{array}{l}\text { Forth review } \\
18 \text { May }\end{array}$ \\
\hline white blood count(3.5-9.5) $\times 10^{9} / \mathrm{L}$ & 4.7 & 6.23 & 5.76 & 6.34 & 8.86 & 10.71 \\
\hline neutrophils $(2-7) \times 10^{9} / \mathrm{L}$ & 3.26 & 3.67 & 3.35 & 3.89 & 5.44 & 6.47 \\
\hline lymphocyte $(0.8-4) \times 10^{9} / \mathrm{L}$ & 1.12 & 1.98 & 1.93 & 1.94 & 2.84 & 3.78 \\
\hline hemoglobin (110-160 g/L) & 117 & 114 & 133 & 146 & 133 & 143 \\
\hline platelet count (100-300) $\times 10^{9} / \mathrm{L}$ & 121 & 192 & 45 & 15 & 62 & 68 \\
\hline Albumin (35-55 g/L) & 36.6 & 35.6 & 45.3 & 53.5 & 41.6 & 42.1 \\
\hline globulin (20-35 g/L) & 26.1 & 24.1 & 31.4 & 35.7 & 24.2 & 20.8 \\
\hline Alanine aminotransferase (> $37 \mathrm{U} / \mathrm{L})$ & 16 & 17 & 30 & 48 & 19 & 22 \\
\hline Aspartate aminotransferase (> $37 \mathrm{U} / \mathrm{L})$ & 20 & 20 & 25 & 42 & 17 & 20 \\
\hline Total bilirubin(> 20.5umol/L) & 2.8 & 4.4 & 10.3 & 12.1 & 9.6 & 8.2 \\
\hline Creatinine (40-133umol/L) & 46 & 59 & 53 & 53 & 62 & 61 \\
\hline Lactate dehydrogenase (109-245 U/L) & 214 & 158 & 159 & 203 & 156 & 216 \\
\hline creatine kinase (25-196 U/L) & 44 & 59 & 41 & 46 & 20 & 32 \\
\hline D-dimer $(0-1 \mu \mathrm{g} / \mathrm{ml})$ & 1.22 & NA & 0.66 & 0.56 & 0.43 & 0.49 \\
\hline Fibrinogen $(0-5 \mu \mathrm{g} / \mathrm{ml})$ & 4.1 & NA & 2.2 & 1.7 & 1.6 & NA \\
\hline C-reactive protein (0-5 mg/L) & 86.34 & 1.3 & 0.83 & 1.29 & $<0.8$ & 0.83 \\
\hline SAA (0-10 mg/L) & $>320$ & 18.08 & $<4.8$ & $<4.8$ & $<4.8$ & 4.93 \\
\hline Procalcitonin $>=0.5 \mathrm{ng} / \mathrm{ml}$ & 0.051 & NA & NA & NA & NA & NA \\
\hline \multicolumn{7}{|l|}{ Lymphocyte subsets (cells/ul) } \\
\hline CD3 + T cells (770-2041) & 736 & 1459 & 1285 & 1018 & 1654 & 2897 \\
\hline CD4 + T cells (414-1123) & 490 & 905 & 734 & 588 & 1163 & 1710 \\
\hline CD8 + T cells (238-874) & 212 & 434 & 412 & 346 & 415 & 936 \\
\hline CD4/CD8 & 2.31 & 2.09 & 1.78 & 1.7 & 2.8 & 1.83 \\
\hline CD19 + B cells (90-560) & 129 & 125 & 166 & 126 & 372 & 370 \\
\hline CD56 + NK cells (150-1100) & 45 & 227 & 208 & 249 & 150 & 302 \\
\hline nucleic acid of SARS-CoV-2 (+/-) & + & - & - & - & - & - \\
\hline Change of the chest CT & $A b$ & $\mathrm{~S}$ & S & S & S & $\mathrm{N}$ \\
\hline \multicolumn{7}{|l|}{ Novel coronavirus specific antibody } \\
\hline $\lg G(+/-)$ & NA & NA & NA & NA & + & + \\
\hline $\lg M(+/-)$ & NA & NA & NA & NA & - & - \\
\hline
\end{tabular}

The follow up of laboratory indicators were in this table from the first admission, mainly including the peripheral blood count, biochemistry indicators, lymphocytes and the result of nucleic acid for SARS-CoV-2. the follow-up was carried out every 15 days after the first discharge.

+ positive, - negative, NA no available, $S A A$ serum amyloid A, $A b$ abnormal, $S$ stable or absorption

infection [14-16], but most of them will gradually recover after antivirus treatment and also the thrombocytopenia was more common in patients in ICU or non-survivors [5, 6]. However, in our report, a non-severe COVID-19 patient without comorbidities and significant lung injury had significant and continuous thrombocytopenia after the nucleic acid for SARS-CoV-2 was negative. The three reexaminations of nucleic acid for SARS-CoV-2 were all negative and the last examination of the specific antibody for SARS-CoV-2 indicated that IgM was negative and IgG was positive, indicating the patient suffered from SARSCoV-2. After taking prednisone for a long time, the platelet count remained low until 4th June 2020, therefore, we highly suspected that the patient had a secondary ITP caused by SARS-CoV-2 infection. Lymphocytes and subsets play a vital role in the maintenance of immune system [9]. The decrease of the lymphocyte and subsets, especially the CD4+ T cells, CD8+ T cells and NK (CD56+) cells was significant, indicating an impairment of the immune system caused by SARS-CoV-2 infection, which might trigger an autoimmune response [17]. CD4+ $\mathrm{T}$ cells help $\mathrm{B}$ cells to produce virus specific antibodies and CD8+ T cells can kill the virus-infected cells by cytotoxicity. Therefore, the depletion and dysfunction of the lymphocytes 


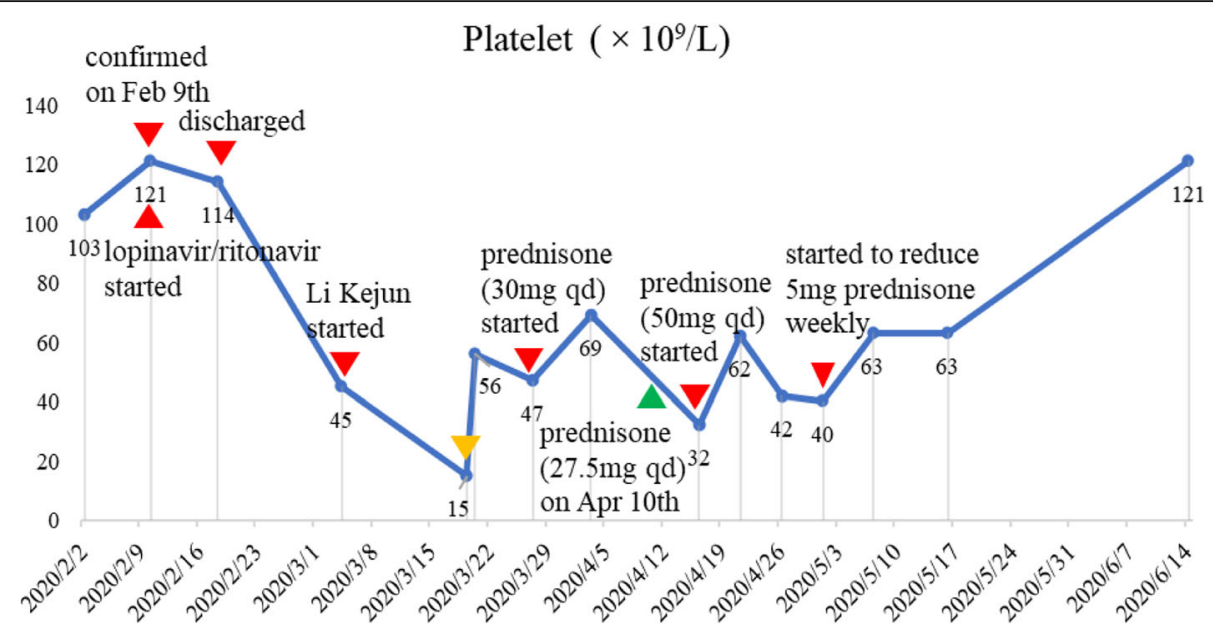

Fig. 1 The change of platelet count and dose of prednisone. The orange triangle on the line means the time when 10 mg of dexamethasone IV were given and platelets transfused. The green triangle on the line means on 10 April 2020, the dose of prednisone was tapered down from 30 $\mathrm{mg}$ to $27.5 \mathrm{mg}$, but without the platelet examination

and their subsets induced the immune system abnormal resulting of thrombocytopenia. We also found that the dynamic characteristic of the platelet count was in consistent with that of the lymphocyte and subsets. Therefore, we deduced that the SARS-CoV-2 might disturb the immune system to induce the thrombocytopenia. Even if nucleic acid of SARS-CoV-2 negative, damage of the immune system might still be present to induce the continuous thrombocytopenia. Now the platelet count has gradually recovered after taking prednisone for about 3 months.

In our paper, excluding other potential factors, we supposed the patient was secondary ITP caused by SARS-CoV-2 infection impairing the immune system.

Table 2 Basic characteristics and personal history

\begin{tabular}{|c|c|c|}
\hline Characteristics & & Medicine history \\
\hline Age & 49 & NSAIDS \\
\hline Sex & female & antibiotics \\
\hline Family history & $\mathrm{N}$ & Immunosuppressors \\
\hline Medical history & & Specific tests \\
\hline immune diseases & $\mathrm{N}$ & Hepatitis B virus \\
\hline chronic gastritis & $\mathrm{N}$ & Hepatitis C virus \\
\hline hyperthyroidism & $\mathrm{N}$ & HIV \\
\hline diabetes & $\mathrm{N}$ & Syphilis \\
\hline hypertension & $\mathrm{N}$ & \\
\hline COPD & $\mathrm{N}$ & \\
\hline chronic liver disease & $\mathrm{N}$ & \\
\hline chronic renal disease & $\mathrm{N}$ & \\
\hline
\end{tabular}

We exclude the potential factors inducing the thrombocytopenia in our report as shown in this table

$N$ no or negative for test, COPD chronic obstructive pulmonary disease, NSAIDS Non-Steroidal Anti-inflammatory Drugs
This damage needs more time to recovery the immune system and platelet count via the glucocorticoid treatment. Although, thrombocytopenia was common in patients with COVID-19, the continuous decrease of platelet in patients after SARS-CoV-2 nucleic acid turning negative was not, which may contribute the clinicians to deal better with these patients. What's more, this rare phenomenon might lead physicians to explore the potential mechanism causing the platelet decrease.

\section{Abbreviations}

COVID-19: Coronavirus disease; SARS-CoV-2: Severe acute respiratory syndrome coronavirus 2; ITP: Immune thrombocytopenia; CRP: C-reactive protein; HIV: Human immunodeficiency virus; SAA: Serum amyloid A; ANCA: Antinuclear antibody; DIC: Disseminated intravascular coagulation; TTP: Thrombotic thrombocytopenic purpura

\section{Acknowledgments}

We sincerely thank to all workers contributed to this report.

\section{Authors' contributions}

$X W$ drafted the manuscript and reviewed the literature. $D L$ and $Y L$ collected the data. YZ and YG revised the manuscript. All authors contributed to obtaining and interpreting the clinical information. All authors read and approved the final version of the manuscript.

Funding

The work was supported by the Chengdu Science and Technology Bureau of Sichuan Province in China (2020-YF05-00034-SN).

Availability of data and materials

All data generated or analyzed during this study are included in this published article.

Ethics approval and consent to participate

Committees of Chengdu Public Health Clinical Medical Center and Hematology department of West China Hospital of Sichuan University both approved this study and written informed consent was given by the patient. 


\section{Consent for publication}

Written consent was obtained from the patient for publication of this case report and the accompanying clinical details and images. A copy of the signed, written informed consent for publication form is available for review by the editor.

\section{Competing interests}

The authors declare that they have no competing interests.

Received: 7 July 2020 Accepted: 8 October 2020

Published online: 19 October 2020

\section{References}

1. Vermeiren C, Marchand-Senécal X, Sheldrake E, Bulir D, Smieja M, Chong S, Forbes JD, Katz K. Comparison of Copan ESwab and FLOQSwab for COVID19 Diagnosis: Working around a Supply Shortage. J Clin Microbiol. 2020; 58(6):e00669-20.

2. Li Q, Guan X, Wu P, Wang X, Zhou L, Tong Y, Ren R, Leung KSM, Lau EHY, Wong JY, et al. Early transmission dynamics in Wuhan, China, of novel coronavirus-infected pneumonia. N Engl J Med. 2020;382(13):1199-207.

3. Xu P, Zhou Q, Xu J. Mechanism of thrombocytopenia in COVID-19 patients. Ann Hematol. 2020:99(6):1205-8.

4. Lippi G, Plebani M, Henry BM. Thrombocytopenia is associated with severe coronavirus disease 2019 (COVID-19) infections: A meta-analysis. Clin Chim Acta. 2020;506:145-8.

5. Zhou F, Yu T, Du R, Fan G, Liu Y, Liu Z, Xiang J, Wang Y, Song B, Gu X, et al. Clinical course and risk factors for mortality of adult inpatients with COVID19 in Wuhan, China: a retrospective cohort study. Lancet (London, England). 2020;395(10229):1054-62

6. Wang D, Hu B, Hu C, Zhu F, Liu X, Zhang J, Wang B, Xiang H, Cheng Z, Xiong Y, Zhao Y, Li Y, Wang X, Peng Z. Clinical Characteristics of 138 Hospitalized Patients With 2019 Novel Coronavirus-Infected Pneumonia in Wuhan, China. JAMA. 2020;323(11):1061-9.

7. Liu Y, Yang Y, Zhang C, Huang F, Wang F, Yuan J, Wang Z, Li J, Li J, Feng C, et al. Clinical and biochemical indexes from 2019-nCoV infected patients linked to viral loads and lung injury. Sci China Life Sci. 2020;63(3):364-74.

8. Liu W, Tao ZW, Wang L, Yuan ML, Liu K, Zhou L, Wei S, Deng Y, Liu J, Liu HG, Yang M, Hu Y. Analysis of factors associated with disease outcomes in hospitalized patients with 2019 novel coronavirus disease. Chin Med J. 2020; 133(9):1032-8.

9. Chen $Y, X i e ~ Y$, Ruan $M$, Shi J. The levels of T lymphocyte subsets in immune thrombocytopenia associated with anti-GPIlb/Illa- and/or anti-GPIbamediated responses are differentially sensitive to dexamethasone. Acta Haematol. 2018;140(1):60-6.

10. Rousan TA, Aldoss IT, Cowley BD Jr, Curtis BR, Bougie DW, Aster RH, George $\mathrm{JN}$. Recurrent acute thrombocytopenia in the hospitalized patient: sepsis, DIC, HIT, or antibiotic-induced thrombocytopenia. Am J Hematol. 2010;85(1): $71-4$.

11. The L. Emerging understandings of 2019-nCoV. Lancet (London, England). 2020;395(10221):311

12. Eickmann M, Gravemann U, Handke W, Tolksdorf F, Reichenberg S, Müller $\mathrm{TH}$, Seltsam A. Inactivation of three emerging viruses - severe acute respiratory syndrome coronavirus, Crimean-Congo haemorrhagic fever virus and Nipah virus - in platelet concentrates by ultraviolet C light and in plasma by methylene blue plus visible light. Vox Sang. 2020;115(3):146-51.

13. Poon TC, Pang RT, Chan KC, Lee NL, Chiu RW, Tong YK, Chim SS, Ngai SM, Sung JJ, Lo YM. Proteomic analysis reveals platelet factor 4 and betathromboglobulin as prognostic markers in severe acute respiratory syndrome. Electrophoresis. 2012;33(12):1894-900.

14. Chang D, Lin M, Wei L, Xie L, Zhu G, Dela Cruz CS, Sharma L. Epidemiologic and clinical characteristics of novel coronavirus infections involving 13 patients outside Wuhan, China. JAMA. 2020;323(11):1092-3.

15. Chan JF, Yuan S, Kok KH, KK T, Chu H, Yang J, Xing F, Liu J, Yip CC, Poon RW, et al. A familial cluster of pneumonia associated with the 2019 Novel coronavirus indicating person-to-person transmission: a study of a family cluster. Lancet (London, England). 2020;395(10223):514-23.

16. Huang C, Wang Y, Li X, Ren L, Zhao J, Hu Y, Zhang L, Fan G, Xu J, Gu X, et al. Clinical features of patients infected with 2019 Novel coronavirus in Wuhan, China. Lancet (London, England). 2020;395(10223):497-506.

17. Audia S, Mahévas M, Samson M, Godeau B, Bonnotte B. Pathogenesis of immune thrombocytopenia. Autoimmun Rev. 2017;16(6):620-32.

\section{Publisher's Note}

Springer Nature remains neutral with regard to jurisdictional claims in published maps and institutional affiliations.

\section{Ready to submit your research? Choose BMC and benefit from:}

- fast, convenient online submission

- thorough peer review by experienced researchers in your field

- rapid publication on acceptance

- support for research data, including large and complex data types

- gold Open Access which fosters wider collaboration and increased citations

- maximum visibility for your research: over $100 \mathrm{M}$ website views per year

At $\mathrm{BMC}$, research is always in progress.

Learn more biomedcentral.com/submissions 